\title{
THE EVOLUTION OF THE FRENCH REGIONAL ECONOMY AND FRENCH REGIONAL THEORY
}

\author{
Niles Hansen*
}

\section{Introduction}

It has been remarked that "Regional development has become a French obsession, a pillar of Government policy as much under Mitterand as it was under de Gaulle or Giscard. And this is irreversible" (Ardagh, 1982: 124). The French system of comprehensive regional planning (amenagement du territoire) was initiated during the postwar years as a response to what was perceived to be overconcentration of population and economic activity in the Paris region and a concomitant neglect of the relatively deprived "French desert," i.e., the provinces (Hansen, 1968). During the 1950 s, the central government encouraged local "expansion committees" and created a system of subsidies and tax concessions to induce firms to shift plants away from Paris or to open new ones in the less developed areas. Restrictions also were placed on the creation or expansion of factories in the Paris region. Despite some successes, the incentives were not sufficiently strong to bring about a significant degree of decentralization. When the Gaullists came to power, decentralization policy was intensified. Large-scale projects were initiated in such lagging areas as Brittany (atomic and space centers) and Languedoc (tourism and irrigation projects), and the ninety departments were grouped into 22 economic planning regions, each with a new coordinating super-prefect. In 1963, a new government agency, the Délégation à l'Aménagement du Territoire et à l'Action Régionale (DATAR) was created to stimulate economic ventures in lesser developed regions and to coordinate these with environmental and infrastructure improvements. However, since the mid-1970s, policy efforts on behalf of lesser developed regions have been diluted because of reconversion measures that have been undertaken in old industrial areas, especially the steel and textile zones of Lorraine and the Nord.

For the past decade there has been a gradual but persistent shift of emphasis in the way in which regional development has been perceived in France. In particular, there has been a relative shift both in theory and in practice away from top-down models in favor of endogenous development at the regional and local levels. There are a

\footnotetext{
*Professor of Economics, University of Texas at Austin. The author gratefully acknowledges the research support provided by the Canadian Institute for Research on Regional Development.
}

number of reasons for this phenomenon. For one thing, after coming to power in 1981, the Socialists stated that the devolution of power to the communes, departments, and regions would be "la grande affaire" of the Mitterand Government. While there was no intention of giving France a federal system along West German, Canadian, or U.S. lines, the reform did, nevertheless, represent a radical effort to alter the nation's highly centralized administrative structure and to strengthen local democracy. Meanwhile, the growth pole approach to regional development-which served as the model for many of DATAR's undertakings--has been falling out of favor with French regional economists and planners, who instead have been giving more consideration to development "from below" of small and medium-size enterprises. This reorientation has no doubt been related to fundamental changes in French regional development patterns and to the factors that have influenced their evolution. The remainder of this paper critically examines the interactions between French regional development processes and recent French regional economic thought, with particular emphasis on insights that may be gained for more general regional development theory and practice.

\section{Interregional Migration}

Much of the literature on French regional development is conditioned by the notion that the "rules of the game" were fundamentally altered with the onset of the period of national and intemational economic crisis that began approximately in 1974 . To be sure, major changes in spatial aspects of French development were already apparent in the late 1960 s, when new behavior patterns were altering life styles and migration flows. Young urban professionals in particular began to exhibit an unprecedented anti-Parisian snobism, and many came to perceive that life in the warm south or near the sea or mountains could be more agreeable than that in Paris. Thus, it has become "almost more chic to say that you live and work in Annecy or Avignon than in Montparnasse-a strange reversal" (Ardagh, 1982: 126).

The coefficient of correlation between French regional per capita income and regional net migration between 1954 and 1962 was 0.87 (Aydalot, 1983a: 92). Throughout most of the 1960 s, interregional migration patterns continued to conform to neoclassical economic logic, with urban polarization, reinforcement of large 
industrial zones, and rural outmigration. However, the correlation coefficient between regional per capita income and regional net migration between 1968 and 1975 was -0.57 . Similar results have been found since then. Moreover, there is no significant correlation between net migration and regional unemployment rates (Aydalot, 1983a: 92-3).

Between 1975 and 1982 Paris and its immediate suburbs lost 220,000 inhabitants. In contrast, rural communes, which accounted for 27 percent of the national population in 1975, recently accounted for 35 percent of all new construction (Aydalot, 1984c: 6). Population in the Ile-de-France-excluding Paris and the ring of immediately adjacent departments--and in the western and southern portions of the Paris Basin increased at twice the national average annual growth rate, which was 0.43 percent betwen 1975 and 1982. The Rhône-Alpes region, which contains Lyon and Grenoble, also grew more rapidly than the nation as a whole during this period. The traditionally lagging regions of the west experienced population growth and, taken as a whole, net inmigration. However, among all French regions by far the most rapid growth took place in the two located on the Mediterranean Sea: Languedoc-Roussillon and Provence-Alpes-Côte d'Azur. Despite an excess of deaths over births, this area grew at over three times the national rate because of very high net inmigration. This phenomenon was rather paradoxical in view of the fact that the Mediterranean regions were experiencing critical problems in the viticultural and agricultural sectors, high unemployment rates, and considerable restructuring within the industrial sector (Bouchet, 1983).

It should be stressed that the general movement of population from the north and northeast toward the regions of the south and southwest cannot be explained by differences in regional incomes, which remain higher to the east of a line from Caen, in Normandy, to Marseille, in the southeast. Rather, recent migration patterns seem more related to cultural processes than to economic variables (Aydalot 1984b, 1985a: 174-75; Pottier, 1984). People are moving away from urban-industrial areas that are losing their traditional environments and lifestyles in favor of places that have retained their regional character. Similarly, changing social values have made it fashionable to remain close to one's traditional provincial roots, which has led to reduced outmigration from less industrial regions. Moreover, rural areas are less and less dependent on agriculture, and the diffusion of transportation and communications has considerably reduced the disadvantages of rural locations with respect to the mobility of goods, persons, ideas, and techniques. In contrast to large, congested urban regions, the most dynamic environments-which, nonetheless, include the Paris region--tend to associate cities that have a relatively high quality of life with a rural milieu that has not been "ruined" by industrialization. Evidence suggests that there is a linkage going from regional net worker migration to regional rate of variation in total employment, but not in the reverse direction and that this process has favored regions which, while not characterized by remarkably high growth rates, nevertheless, have attributes that accord with widespread aspirations concerning quality of life and quality of the environment.

\section{Changing Industrial Structures}

The postwar pattern of French industrialization, as that of nineteenth century, was based on heavy industry characterized by large, concentrated oligopolies, advanced technologies, and large-scale investment undertakings, all of which were accompanied by a high degree of spatial concentration. In the 1950 s, over a quarter of total national industrial employment was located in the Paris region alone. However, as labor became more scarce and more expensive in the Paris region, there was a decentralization of industrial employment in favor of smaller towns and rural areas. In 25 years, Paris-based firms created 500,000 jobs in the provinces (Aydalot, 1985b). The decentralization of manufacturing was consistent with the theory of the product cycle. That is, when a product reaches the mature phase of the cycle there is little technological innovation, and the standardized output is manufactured in long, routine production runs. Because large amounts of specialized equipment are often used, capital intensity may remain relatively high, but the key human input is cheap, low-skilled labor. In order to remain competitive, firms respond to changing input-mix needs--corresponding to different phases of the product cycle--by changing the geographic location of production. The French evidence indicates that the great wave of manufacturing decentralization was carried out independently of government decentralization subsidies. A 1975 survey showed that only 30 out of 788 such operations were influenced by subsidies. Nonaided areas attracted most of the plants, and workers in these plants came from "the privileged reservoir of unskilled labor. women, rural residents, immigrants, and young persons" (Aydalot, 1978: 251).

Since the beginning of the crisis in 1974 large oligopolistic firms have on balance laid off industrial workers. Meanwhile, for the first time since the beginning of French industrialization, small and medium size firms have been coming to the fore and increasing their share of industrial employment. Moreover, the regions that have displayed the greatest economic vitality in recent years have been those where large oligopolies are the least in 
evidence, and where the proportion of small and mediumsize firms is relatively high (Aydalot, 1985b). In comparison with firms in the old industrial regions, those in the regions of the south and west have less need to undertake radical technical adaptations, which limits the need to substitute capital for labor. Although the south and west are relatively specialized in industries that face increasing competition from low-wage developing countries, their products tend to be protected by the specialized demand of French consumers as well as French-utilizing industries. Moreover, labor in the small and medium-size firms of the south and west is less costly than that in old industrial regions, and the workers are less organized and less militant. In view of the extension of transportation and communications and the absence of urban-industrial congestion, firms have been able to reap the benefits of the labor market at the same time that white-collar and technical employees have been able to realize their aspirations with respect to quality of life considerations (Pottier, 1984).

The resurgence of small and medium-size firms since the beginning of the crisis in 1974, after over a century of continuous concentration of employment in large firms, is one of the more remarkable attributes of the contemporary French economy. Data on the evolution of employment by size of establishment are presented in Table 1.

Table 1

Change in Employment (Thousands) by Size of Establishment, 1969-1973 and 1974-1980

\begin{tabular}{lcccrc}
\hline \multicolumn{1}{c}{$\begin{array}{c}\text { Size of } \\
\text { Establishment }\end{array}$} & \multicolumn{2}{c}{$\begin{array}{c}\text { Absolute Change } \\
\text { (thousands) }\end{array}$} & \multicolumn{2}{c}{$\begin{array}{c}\text { Percent } \\
\text { Change }\end{array}$} \\
& $1969-1973$ & $1974-1980$ & $1969-1973$ & $1974-1980$ \\
\hline Small (1-19 employees) & +166 & +555 & +5 & +16 \\
Medium (20-199 employees) & +712 & +150 & +17 & +3 \\
Large (200 or more employees) & +863 & -557 & +22 & -12 \\
Total & $+1,741$ & +148 & +15 & +1 \\
\hline \hline
\end{tabular}

Source: Xavier Greffe, Territoires en France. Paris: Economica, 1984, p. 56.

The figures represent most paid employment, but do not include workers in agriculture, public administration, and public enterprises. During the $1969-73$ period employment grew by 300,000 to 400,000 workers per year, with the greatest increases being accounted for by large establishments, that is, those with 200 or more employees. With the onset of the crisis, total employent remained relatively stable over time. However, this aggregate stability masked major differences by size of establishment. Between 1974 and 1980 employment in large establishments declined by 557,000 workers, but it rose by 705,000 in the other two categories; small establishments alone accounted for an increase of 555,000 workers, a 16 percent gain. If one examines only the evolution of manufacturing employment, in view of the fact that service establishments are often small, similar results are obtained. The data in Table 2 indicate that manufacturing employment declined in medium-size and large establishments between 1974 and 1980. In contrast, whereas employment in small establishments declined between

Table 2

Change in Employment (Thousands) in Manufacturing, by Size of Establishment 1967-1973 and 1974-1980

\begin{tabular}{lcc}
\hline \hline Size of Establishment & $1967-1973$ & $1974-1980$ \\
\hline Small (1-19 employees) & -104 & +37 \\
Medium (20-199 employees) & +154 & -156 \\
Large (200 or more employees) & +585 & -495 \\
\hline \hline
\end{tabular}

Source: Xavier Greffe, Territoires en France. Paris: Economica, 1984, p. 57. 
1967 and 1973, it increased in the $1974-1980$ period. The overall employment change patterns shown in Table 2 were also characteristic of most industrial sectors.

Other studies indicate that the proportion of French workers accounted for by firms with fewer than $50 \mathrm{em}$ ployees increased from 43.1 percent in 1976 to 49.1 percent in 1983. The number of small and medium-size firms created between 1981 and 1983 averaged 68,000 per year; the corresponding figures for 1984 and 1985 were 73,000 and over 103,000 , respectively, or a 20 percent increase over the last two years (Gatel and Passaris, 1986: 4).

The increase in importance of small and mediumsize firms can be explained in part by factors associated with the crisis, which changed the industrial decentralization strategy pursued by large firms. These factors included increased transport costs caused by the energy crisis, the closing of some mass consumption markets, a diminution of interregional wage differences, and a decrease in the real value of government decentralization subsidies. The efforts made by large firms in order to adapt to the changing economic environment resulted in plant closings, increased automation, and the exportation of some activities. The consequent rise in unemployment was particularly marked among relatively low-skill workers in local labor markets that experienced growth during the years of industrial decentralization. Survey evidence (Perrin, 1983) indicated that over 70 percent of the bluecollar workers were in the unskilled category in only 29 percent of the non-decentralized plants of large firms; however, this was the case in 59 percent of the decentralized plants of large firms, and in 43 percent of the small and medium-size local firms. Similarly, Aydalot (1983b: 183-85) estimates that the ratio of unskilled workers to skilled workers was 1.05 in Paris, 1.44 in communes with between 50,000 and 100,000 inhabitants, 1.89 in communes with between 5,000 and 10,000 inhabitants, and 2.03 in rural communes. In terms of regions, the proportion of unskilled workers was 17 percent in the Paris region, 27 percent in the North, 33 percent in the Southwest, 44 percent in the Southeast, and 56 percent in the Paris Basin.

Local areas where unemployment was especially severe typically lacked the decision-making capacity and human resources capable of initiating new local development projects. But it was precisely this dilemma that gave a strong impetus, both in the regional economic literature and in local practice, to find possibilities for the development of local entrepreneurship. Thus, Aydalot (1983a: $101,104)$ argues that in place of an imported but tenuous regional economic dynamism, to which whole regions had become accustomed, it is now necessary to substitute an interior dynamism, which alone can bring about genuine development. In terms of theory this implies a movement away from the top-down center-periphery analyses that fairly accurately described spatial economic processes during the 1950-1975 period, in favor of the analysis of "regional production processes" that take into account the interrelated technical, social, organizational, and spatial aspects of production. Furthermore, efforts in this regard, which have begun only relatively recently, need to take account of the fact that since the onset of the crisis, the phenomena that have been primarily responsible for generating development have been service firms in technologically advanced sectors and small, locally created industrial firms.

\section{The Role of Producer Services}

Growth pole theory and economic base theory have both regarded industrial expansion as the major factor in regional economic development. In these contexts the tertiary sector has been treated essentially as a residual, resulting from industrial development and population growth, and therefore not in need of policy measures in its own right. In recent years, however, increasing attention has been given to the developmental role of the tertiary sector in general and producer services in particular. The growing importance of tertiary activities is not a phenomenon that opposes goods and services, but rather involves a combination of the two. Goods manufacturing involves increasing amounts of non-material inputs as firms devote more of their resources to research and development, engineering, distribution, marketing, management, and planning. Goods manufacturing is also associated with tertiary employment in related sectors. For example, considerable employment in tertiary activities is linked to auto production: auto sales and repair, transportation, driver training, car rentals, insurance, and tourism agencies. In 1980, the French auto industry employed 500,000 persons (many of whom were in internal producer services occupations), but employment in linked tertiary sectors was about twice as great (Bailly and Maillat, 1986: 30). More generally, the growth of producer services in France has proceeded rapidly since the 1960s; employment in this regard rose from 4.8 percent of total tertiary employment in 1962 to 8.1 percent in 1980 (Bailly and Maillat, 1986: 43).

Valeyre (1985) has analyzed the spatial dynamics of tertiary jobs linked to French manufacturing from the beginning of the century to 1975 , showing how the growth of employment in producer services within and external to firms has been related to increases in the division of labor. Internal and external producer services have a similar 
spatial distribution. The Paris region has a very high concentration of employment in such activities. In contrast, the situation is relatively unfavorable in the West, the Massif Central, and Franche Comte, while the Southeast occupies a middle position. In 1975 the Paris region accounted for 22 percent of total French employment, but the region's share of producer services was 41 percent, and reached 55 percent in technical engineering services and data processing, 61 percent in advertising, and 61 percent in marketing research. As a consequence of spatial concentration, provincial manufacturing firms often must turn to national producer-service firms, usually Parisian, for such high-level services as research, advertizing, marketing, and management consulting. The demand for highly specialized external producer services is particularly high among large multiplant manufacturing firms. Such services tend to locate near the decisionmaking centers of the most important, large enterprises, which are much more geographically concentrated than are small and medium-size firms. The latter have relatively little effective demand for external producer services, with the exception of accountants and bankers. Moreover, because producer-service firms are oriented toward the needs of large firms, they often are not very responsive to the needs of small firms. Thus, even a dense concentration of small and medium-size firms has not sufficed to attract producer services. It should be emphasized, however, that these findings only concem the period up to 1975 because of a lack of more recent comparable data. The industrial restructuring and diffusion of transportation and communications that have taken place since then have the potential to transform information networks and industrial organization, which in turn could reverse the long-run tendency toward geographic concentration of production in favor of a more balanced development among the different regions.

Planque $(1982 ; 1984)$ has argued that the revolution in transportation and communications facilities, the diffusion of data processing capabilities, and the diseconomies of large urban agglomerations already have combined to create a solid basis for a decentralization of population and economic activity that is qualitatively superior to the industrial decentralization of the pre-1975 years. However, in view of the persistence of spatial inequalities and the limited extent of decentralization to date, Cunha and Racine (1984) maintain that any expectation of dynamic processes that will automatically reduce regional inequalities is premature. In particular, although the decentralization of producer services is neither technically nor economically insurmountable, their growth in peripheral areas is not likely to occur spontaneously. External relationships of industrial firms already are more a matter of industry-teritary linkages than of industry-industry linkages, and this is likely to reinforce the advantages of major urban centers that already possess most of the sophisticated producer services. Thus, although the potential for decentralization is present, it is not likely to be realized in significant degree without public policy measures that reinforce the endogenous potentials of peripheral regions. Monnoyer (1984) similarly points out that producer-service activities are dependent on their markets, but even more so on the quality of the skills locally available to them; therefore, their expansion in a region presupposes the existence of a highly educated and creative work force.

Relevant Swiss evidence (Bailly and Maillat, 1986; Bailly, Maillat and Rey, 1984; Maillat, 1984) also indicates that a network of producer services is indispensable for assuring liaisons between small and medium-size firms and external markets. However, the development of regional producer services depends in turn not only on the number and importance of client firms, but also on the presence of one or several medium-size cities with attractive characteristics. Such services have been a driving force in the development of the small and medium-size firms that have been at the vanguard of the renewal of a number of regional production systems. They have had either direct regional multiplier effects through the exportation of specialized services or indirect regional multiplier effects through their liaisons with exporting manufacturers. Regional producer-services firms have variously provided risk capital, advice concerning the settingup of innovative new firms, an interface between research centers and small and medium-size firms, and an interface between such firms and markets. Nevertheless, for historical reasons firms in industrial regions in need of restructuring have still not accorded sufficient importance to the positive role of producer services, and when they do have resort to these services they often, from habit, seek them outside of their own regions. Students of these phenomena have pointed out that "in the context of reconstituting regional production systems, this is why regional policy should increasingly promote the development of spatially non-hierarchical producer services" (Bailly, Maillat, and Rey, 1984: 766).

\section{Local Dynamism and Technological Change}

In France, as elsewhere, virtually all regions attach considerable importance to high technology activities in seeking solutions to their economic problems. In this regard they may take solace from a recent Organization for Economic Cooperation and Development report (OECD, 1986) on French national innovation policy, which finds 
that there may be an inherent conflict between the organization of French research and the new patterns of economic growth. The traditional system, which emphasizes elite education and top-down, state-led, large-scale programs, may no longer be consistent with the stimulation of development and employment. It is increasingly clear that technology contributes to economic development through a bottom-up process in which small and medium-size firm formation, entrepreneurial activities, diffusion of new technologies, and a large pool of skilled human resources are the critical factors. In regional terms, this implies a spatial decentralization of funding from the central government, so as to promote the growth of competitive markets that implement the diffusion of innovation. Innovation policies should not be bureaucratized at the regional level, but should rather be targeted directly at small and medium-size firms. The report further suggests that generic technologies should be diffused throughout the industrial fabric and that the Agency for the Valorization of Research's ability to support local initiatives should be strengthened.

It is noteworthy that the growth pole orientation that characterized much of French industrial development policy in the years prior to the crisis has paralleled certain research activities. The California model, and Silicon Valley in particular, represented an example for emulation with respect to the polarization of advanced technology firms that were "footloose" in terms of traditional industrial location criteria. In this regard the French Riviera appeared to be an especially promising region. IBM established a major research laboratory at La Gaude, a village near Nice, not only because of its proximity to an international airport, but also because of its proximity to sun, sea, and mountain amenities as well as a university capable of providing researchers and engineers (Aydalot, 1984a: 52). After Texas Instruments located in the same area, the French government decided to create near Nice a "city of science," Sophia Antipolis, that would concentrate a variety of research activities. In keeping with the Silicon Valley model it was expected that numerous small-scale initiatives would be induced by the presence of a few large high technology enterprises. Although some large French and foreign firms were attracted to the Sophia Antipolis complex, they tended to set up research centers but only a very few manufacturing plants (Pottier, 1985). Moreover, the research activities of the complex had no relevance to existing local manufacturing firms, so the diffusion effects on local growth were minimal (Philippe, 1986). In view of the fact that the relationship between research and manufacturing is far less close in France than in Japan and the United States, Pottier concludes that France "must avoid relying on the mirage of local development initiated by the creation of research complexes, despite the fact that this is a fashionable notion," and instead emphasize decentralized research centers linked to dominant reigonal activities (Pottier, 1985: 71).

The positive role that technological change can play in restructuring local economies has been receiving increasing attention in France. Perrin's (1984) analysis of how new structures emerged from older ones in the Ales Bassin, some sixty miles north of Marseille, has been particularly influential. Perrin argues that local systems do not just incorporate technological progress, but also produce it and that local dynamism tends to reinforce itself. During the 1950s the Alès Basin was a medium-size industrial area characterized by the extraction and processing of natural resources. Between 1954 and 1980 employment in the area's coal mines declined from 15,000 to 1,200 workers. Meanwhile, thousands of jobs were also lost in such other traditional sectors as textiles, forestry, food processing, and construction materials. Yet contrary to what might have been expected, this isolated old industrial region experienced a remarkable rejuvenation by incorporating technological progress in a series of development phases. First, large local engineering and chemical plants that had been established before 1960 continued to develop technologically more sophisticated products and to improve worker skills. From 1960 to 1970 branch plants in the textile and electrical equipment sectors were located in the area. In keeping with the nature of French industrial decentralization during this period, the relevant activities involved mass production using low-skill labor. Beginning in the mid-1970s, the area attracted more externally-controlled branch plants--at first in the electrical equipment sector and later in numerous other sectors--that utilized new technologies and relatively skilled labor. Then from 1978 on, numerous small and medium-size firms were created; these high technology, high-skilled local undertakings have been largely export- oriented. Meanwhile, there has been rapid growth of employment in induced local producer-service firms, whose existence has in turn made the area still more attractive for small and medium-size industrial enterprises. Today the economic structure of the Ales Bassin is diversified and modern, with strong endogenous interindustry linkages.

The restructuring of the Ales economy was initiated and sustained by two phenomena that have been generally characteristic of successful French medium-size local systems since the crisis: the introduction of new technologies and the emergence of concerted local development initiatives. The breakthroughs in terms of technological advance occurred in 1975 , when skilled labor was created 
by a major new electrical equipment plant, and between 1978 and 1982, when sixteen local firms were formed. The presence of numerous local decision-making centers in Ales has reduced external dependence and enhanced internal integration and dynamism, particularly through spontaneous formal and informal collective planning mechanisms that address development issues. A strong technical and general education system guarantees a supply of skilled males and females who are adaptable to new technologies. Moreover, the labor market is open and flexible because it is not dominated by one or a few large firms. The restoration of mining sites and the provision of urban amenities has been undertaken to provide a high quality of life. In addition, an agency assists entrepreneurs by introducing them to business associations, finding appropriate plant sites, helping them to obtain financial assistance, and by helping to relocate employees coming from outside the area. The restructuring of Alès and similar experiences in other French communities suggests that the study of local economic dynamism should not be limited merely to industrial sectors, tertiary activities, exports, or other particular economic variables, but should rather treat this process in broad socio-economic terms, as a vital ecosystem that can acquire the capacity to innovate (Perrin, 1984: 253).

It should be pointed out that emphasis on local development potentials does not imply an autonomous, development-from-below strategy. Local systems are not incapable of dealing with the consequences of the global technological revolution or the new international division of labor. Local dynamism based on small and mediumsize firms can involve both a high degree of endogenous decision-making control and extensive networks of external contacts.

The French regional economics literature frequently advises regions and communities not to bet their economic futures on interventions by large external industrial enterprises. The nature of industrial decentralization that typified the pre-1975 period--branch plants, routine production, low-skill labor--and the fact that large industrial firms have cut back employment during the crisis years lend considerable credence to this view. Nevertheless, some large industrial firms have initiated programs to support local development by establishing linkages with numerous innovative small and medium-size firms. Such programs have provided valuable logistical support in terms of research centers, provision of land, and financial assistance, typically through loans, rather than capital participation (Gatel and Passaris, 1986). Rhône-Poulenc, for example, made an inventory of small high technology firms to identify promising enterprises that had not been able to take advantage of their patent rights or had not been able to market their products. Some hundred small firms received contracts as a result. Similarly, Pechiney Ugine Kuhlman established a program of cooperation with regional small and medium-size firms seeking to ameliorate their cash-flow by selling technologies abroad. The program involves common international marketing and contracting as well as the direct association of small firms in large-scale projects where PUK needs their complementary activities (Greffe, 1984: 63-64).

An emphasis on fostering local development potentials also does not imply that the central government should simply leave individual communities and regions to their own devices, especially in matters of technogical innovation and adaptation. Numerous government institutions and authorities have, in fact, been created to promote local initiatives in one manner or another, but they have been slow to change their traditional modes of operation and their habit of being unresponsive to the specific needs of persons attempting to initiate small scale projects (Gatel and Passaris, 1986). For example, public regional research centers have tended to work through the intermediary of Chambers of Commerce, instead of working directly with small and medium-size firms. Because such centers have acted more as providers of general information than as partners seeking specific solutions to firms' specific needs, they have not been genuine catalysts for technological progress (Philippe, 1986). To be more effective they need to identify the specific technological requirements of small and medium-size firms and then express them in scientific terms for research institutions. Conversely, they should also be aware of technological information that may be valuable to firms, even though the latter have not specifically solicited aid. In sum, regional research centers need to provide an active interface between firms and research institutions (Maillat, 1984).

Finally, the important role that banks and other financial institutions have in local development is evident. The experience of other countries indicates that it is vital to have the financial means to support not only the commercialization of products, but also the different phases of technological innovation processes. In France the lack of risk capital in this regard remains a significant impediment to local economic dynamism.

\section{Conclusions}

The French regional development (amenagement du territoire) model that prevailed during the 1960 s was essentially top-down in nature. It was based on largescale, spatially-concentrated industrial and infrastructure investments, with decision-making largely in the hands of large industrial oligopolies and financial institutions. The 
prevailing conceptual basis for regional planning was growth pole theory, whose influence eventually extended throughout the world. Although a considerable amount of industrial decentralization took place in this context, the quality of the decentralized jobs left much to be desired. In retrospect, it is apparent that externally-induced growth typically did not provide a solid basis for sustained regional or local development.

The general economic crisis that began in the mid1970s has changed the nature of French regional development as well as the theoretical orientations of French regional economics. The traditional oligopolies of the old industrial regions have had great difficulty in adapting to the new international division of labor, and government policies to support these enterprises may, in fact, have retarded needed restructuring. Meanwhile, economic dynamism has tended to be associated with small and medium-size firms, though a note of caution needs to be made in this regard. The average levels of wages, salaries, and fringe benefits are lower than in large firms, and often employment is more unstable. Moreover, the "new potential" of small and medium-size firms partly reflects the general expansion of tertiary activities and the fact that firms in the tertiary sector are typically smaller than manufacturing enterprises. Nevertheless, small and medium-size firms have been accounting for much of the employment growth in technologically advanced activities, and they are regarded as more adaptable than large firms. While many of these businesses are located in Paris and other large urban areas, a large number have also spontaneously emerged in the south and west, regions that have been regarded as less developed. Population migration patterns, which cannot be explained in purely economic terms, have also favored less industrial areas that have maintained their traditional regional character. In view of these phenomena, the French regional economics literature has been emphasizing the developmental roles of technological innovation and producer services, as well as their introduction within the framework of endogenous regional and local development initiatives, a process that appears to be social and cultural as well as economic in nature.

Large-scale infrastructure projects, which play an important role in the growth pole approach to development, now receive less attention, probably because most regions now have adequate infrastructure. In any case, it is difficult to base regional policy on the improvement of infrastructure in less-developed French regions, because in many instances, such regions already have the highest levels of infrastructure endowments (Navarre and Prud'homme, 1984).

In view of the national priority that is attached to macroeconomic difficulties, it is frequently argued that the role of regional policy in France should be the revitalization of local economic development environments, rather than attemps to influence the movement of economic activity from one area to another, which regional policy can only marginally influence in any case. This is especially so because the newly-strong regions are still less rich than the newly-weak regions; since each group feels disadvantaged in its own way, it cannot be expected that one will subsidize the other in the name of national regional planning. Rather, regional planning needs to be carried out in a more decentralized institutional and administrative context in order to facilitate locally-generated development initiatives (Aydalot, 1984a: 55-58). In terms of economic analysis, the present situation suggests that there should be a relative shift of emphasis from the theory of firm location in favor of the theory of the development of an innovative milieu and from models based on the diffusion of extemally-generated processes in favor of models of endogenous development. The efforts that have been made in these regards have been largely exploratory, yet they do, nevertheless, suggest promising paths for the revitalization of policy-oriented regional economics and regional science.

\section{REFERENCES}

Ardagh, John. France in the 1980s. New York: Penguin Books, 1982.

Aydalot, Philippe. "L'Aménagement du Territoire en France: Une Tentative de Bilan." L'Espace Geographique. 7 (1978). 245-253.

- "Crise Economique, Crise de l'Espace, Crise de la Pensée Spatiale." In Bernard Planque (ed.). Le Développement Décentralisé. Paris: Presses Universitaires de France, 1983a. 87-105.

. "La Division Spatiale du Travail." In J. H. Paelinck and A. Sallez (eds.). Espace et Localisation. Paris: Economica, 1983b. 175-200.

"A la Recherche des Nouveaux Dynamismes

Spatiaux." In Philippe Aydalot (ed.). Crise et Espace.

Paris: Economica, 1984a. 38-59.

- "Note sur les Migrations Interrégionales en France,

1975-1982." Paris: Cahier No. 40, Dossiers du Centre

Economie, Espace, Environnement, Université de Paris I, June 1984b.

"Questions for Regional Economy." Tijdschrift voor Economische en Sociale Geografie. 75 (1984c). 4-13. Economie Régionale et Urbaine. Paris: Economica, 1985a.

"Prise en Compte des Facteurs Spatiaux et Urbains dans la Politique de Développement." Revue d'Economie Régionale et Urbaine. No. 2 (1985b). 167-180. 
Bailly, Antoine and Denis Maillat. Le Secteur Tertiare en Question. Paris: Anthropos, 1986.

Bailly, A. S., D. Maillat, and M. Rey. "Tertiare Moteur et Développement Régional: Le Cas des Petites et Moyennes Villes." Revue d'Economie Régionale et Urbaine. No. 5 (1984). 757-776.

Bouchet, Jean. "Mouvements Démographiques et Evolutions du Territoire: Eléments de Problématique." Revue d" Economie Régionale et Urbaine. No. 5 (1983). 669-692.

Cunha, Antonio, and Jean-Bernard Racine. "Le Rôle des Services aux Enterprises dans une Société PostIndustrielle." Revue d'Economie Régionale et Urbaine. No. 5 (1984). 731-756.

Gatel, Jean and Solange Passaris. "Le Développement Local: Des Territoires, Des Hommes, Des Initiatives, Le Partenariat." Revue d'Economie Régionale et Urbaine. No. 1 (1986). 3-8.

Greffe, Xavier. Territoires en France. Paris: Economica, 1984.

Hansen, Niles. French Regional Planning. Bloomington: Indiana University Press, 1968.

Leo, Pierre-Yves. "Les Nouvelles Formes de la Mobilité des Industries en France." In Barnard Planque (ed.). Le Développement Décentralisé. Paris: Presses Universitaires de France, 1983. 45-65.

Maillat, Denis. "Les Conditions d'une Statégie de Développement par le Bas: Le Cas de la Région Horlogère Suisse." Revue d'Economie Régionale et Urbaine. No. 2 (1984). 257-273.

Monnoyer, Marie-Christine. "Evolution du Marché des Services aux Enterprises et Formulation de Stratégies de Développement pour les Activités de Services: Implications Régionales." Revue d' Economie Régionale et Urbaine. No. 5 (1984). 777-791.
Navarre, Françoise and Rémy Prud'homme. "Le Rôle des Infrastructures dans le Développement Régional." Revue d'Economie Régionale et Urbaine. No. 1 (1984). 5-22. OECD Observer, No 140, May 1986. 9-13.

Perrin, Jean-Claude. "Economie Spatiale et Mésoanalyse." In J. H. Paelinck and A. Sallez (eds.). Espace et Localisation. Paris: Economica, 1983. 201-230.

"La Reconversion du Bassin Industriel d'Alès: Contribution à une Théorie de la Dynamique Locale." Revue d'Economie Régionale et Urbaine. No. 2 (1984). 237-256.

Philippe, J. "Les Services aux Enterprises et la Politique de Développement Régional." In Bailly and Maillat. 117121.

Planque, Bernard. Innovation et DÉveloppement Régional. Paris: Economica, 1982. "Observations et Interprétations de la Dynamique Spatiale Contemporaine." In Bernard Planque (ed.). Le Développement Décentralisé. Paris: Presses Universitaires de France, 1983. 5-26.

"Technologies Nouvelles et Reorganisation Spatiale." In Philippe Aydalot (ed.). Crise et Espace. Paris: Economica, 1984. 98-121.

Pottier, Claude. "Facteurs de Réquilibrage Spatial de l'Emploi Industriel, Les Régions Françaises Face à la Crise." In Philippe Aydalot (ed.). Crise et Espace. Paris: Economica, 1984. 122-39. - "The Adaptation of Regional Industrial Structures to Technical Changes." Papers of the Regional Science Association. 58 (1985). 60-72.

Valeyre, Antoine. "La Dynamique Spatiale des Emplois de Service Liés à la Production Industrielle." Revue d' Economie Régionale et Urbaine. No. 4 (1985). 703-725. 